\title{
ESA faces economies to pay for Ariane launch failure
}

Paris. The explosion of Europe's Ariane-5 satellite launcher on its maiden flight last June will add ECU288 million (US\$362 million) to the cost of the programme, and delay the full commercial exploitation of the launcher by a year to early 1998 .

These and other details of how the Ariane-5 programme is to be resumed following the explosion were announced last week at a press conference in Paris by Jean-Marie Luton, director general of the European Space Agency (ESA), and Alain Bensoussan, president of the French space agency (CNES).

Two further qualification flights of Ariane-5 are now planned, the first next April and the second next September. The first will carry only a payload of instruments to evaluate the performance of the launcher, and a 500-kg AMSAT satellite of the International Association of Radio Amateurs. The second will carry a demonstration model of a planned European atmospheric re-entry vehicle.

These dates are only targets, however, and may be postponed if necessary. Indeed, before the next launch, ESA intends to go beyond the recommendations of the explosion inquiry board and to re-examine the entire qualification system.

The Ariane-5 launch failed because of software errors that went undetected during tests and caused the rocket to veer off course and break up. The re-examination will consider in particular how the launcher would perform in highly 'degraded modes' - after the failure of one or more systems and their back-ups - and take steps to cover such eventualities.

The cost of the work required is estimated at ECU154 million, while the extra qualification flight will cost ECU134 million, giving a total bill of ECU 288 million. This will make a large hole in the ECU1.72 billion budget agreed for the programme between 1996 and 2003 (see Nature 377, 667; 1995).

Luton says that the money will have to be found from within existing budgets. Economies will be needed in other ESA programmes, such as plans to expand Ariane-5's capabilities, says Luton. He is also hoping to obtain contributions from industrial groups involved in the programme.

ESA's space science programme is unlikely to be directly affected by the economies. Its budget is agreed every three years by ESA ministers, and any reduction would require a unanimous vote. This would "be opposed", says Roger
Bonnet, head of the science programme.

But Bonnet warns that money could be taken from the space science programme in more indirect ways, such as charging it for services that have until now been provided free. Similarly, the increase in pressure on already strained budgets may make it more difficult for member states to afford the costs of building their payloads and will increase pressure for the space science programme to contribute to these costs.

Space science was notably absent from the agenda at last week's press conference, and no mention was made of plans to replace the Cluster project (see Nature 383, $111 ; 1996)$, whose four satellites were lost in the explosion. Ominously perhaps, ESA's ECU288-million estimate of the financial

IMAGE
UNAVAILABLE
FOR COPYRIGHT
REASONS

Bioethics group finds 'no objection' to human gene patents

Munich. A group of ethics advisers to the European Commission in Brussels says that it has found no ethical reason why a human gene should not be patented by its 'discoverer' if it can be shown that it has a function with a specific industrial application.

But, in a statement last week, the group added that it should not be possible to patent the simple knowledge of the structure of a complete or partial gene sequence without identifying its function. Such a patent would not meet the primary requirements of novelty, inventive step and industrial application.

The group was asked by the commission last April to consider the ethical implications of patenting material of human origin, as part of a wide consultation process intended to help smooth the passage of a European directive on the patenting of biotechnological inventions. An earlier directive failed to win the vote of the European Parliament last year, partly because of ethical concerns (see Nature 374, 103; 1995).

The group is made up of nine bioethics experts, and is chaired by Noëlle Lenoir, a member of France's constitutional court. In a formal opinion delivered to the commission, the group says that, in accordance with the ethical principle that the human body should not be commercialized, a person donating samples from which a patented gene is derived is not entitled to payment. But the person should be fully informed and provide full consent. Patents should not be granted on a human body or parts of a human body, says the group.

One member of the group, Dieter Mieth, professor of scientific ethics at Tübingen University in Germany, dissented, saying that human genes should be patentable only if their structure has been altered.

The advisory group's opinion has been welcomed by the commission, as it coincides with the thrust of the new directive, which faces its first reading in the European Parliament early next year. According to Willi Rothley, deputy chairman of the parliament's committee of legal affairs, which will introduce the directive, a "clear majority" of Members of the European Parliament are now in favour of it. This is a result of the commission's extensive consultation process and consequent modification of the text (see Nature 378, 756; 1995).

Approval of the directive by the Council of Ministers, which requires a simple majority vote, also seems certain, with only Denmark likely to voice objection.

Alison Abbott 